\title{
TEACHING ENGLISH TO NON-ENGLISH STUDENTS' DEPARTMENT AT ISLAMIC UNIVERSITY OF INDONESIA THROUGH FORMULA 33: STUDENTS' REFLECTIONS
}

\author{
Nizamuddin Sadiq \\ Islamic University of Indonesia
}

\begin{abstract}
Results of students' need analysis show that grammar (tenses) is the students' lowest ability that they wanted to learn at that time. In order to cope with that contextual situation, Formula 33 is proposed to be the main concern on the learning English for students of non-English deparment at Islamic University in the academic year 2012/2013.

Students must write reflections - express their emotion and knowledge gain in the form of essay to e-learning provided - every time the class end. The students' reflections were considered as data. The data were classified based on some categories/themes descriptively. Those data are then read very carefully to find out the keywords that became the instruments to classify them into themes, while irrelevant data were sorted.

The results show that learning English through Formula 33 addressed in three aspects - learning domain, teaching delivery, and students' best practice. In learning domain, students have positive and negative cognitive feedback. Formula 33 was considered improving their skills especially in writing English sentences with correct grammatical structure as well as they have excellent attitude toward Formula. In teaching delivery that consists of two keywords method and materials. Students said that both method and materials are super.
\end{abstract}

Key words: Formula 33, positive and negative cognitive feedback, teaching delivery

\section{INTRODUCTION}

In academic year 2012/2013, I taught English for non-English students' for five classes two classes of Architecture, two classes of Pharmacy, and one class of 
Psychology. The material that I was given was learning English through Formula 33. Formula 33 is a system of knowledge of English grammatical patterns that combines verbal, nominal and passive into one comprehensive and well-rounded concept (Sadiq, 2012: 6).

There are several reasons why learning English through Formula 33 was the core material for them. The first and the most important reason is a time frame. As we know that there are only fourteen meetings available in which each meeting consist of only a hundred minutes. An instructor or a lecturer must adjust the two poles of that materials are too many at one side and of that time available is too limited at other side. Therefore, designing materials in limited time frame must be wise and realistic. The last reason is skill driven encouragement. Because of the time frame is restricted, it is important to think of that students can develop themselves with the English lesson they took when they have finished learning it. Therefore, to provide students with practical skills and to prolong their building skills of English, Formula 33 is appropriate for that purpose (Sadiq, 2012:3-6).

Furthermore, the materials were given in three steps. The first step comprehended the concept of VNP Verbal, Nominal, and Passive. Followed by the second step the concept of Time and Aspect and the last step was activating the Formula 33 by doing some exercises. Ensuring these three steps ran well, a special room for writing reflection after heading step-by-step process was available.

Reflection is a combination between what students' felt in the classroom when they attended a class and what knowledge students got when they learnt the materials given. This was a personal expression written in the form of essay. In addition to ensure the process of internalizing the Formula 33, another benefit of reflection was that instructor or lecturer can improve the teaching method and material design.

\section{THEORETICAL FRAMEWORK}

Teaching English for non-English Department at universities in Indonesia often refers to ESP English for Specific Purposes. This idea is much influenced by the concept of ESP in the English speaking countries. For more specific way, as defined by Hutchinson and Waters (1987: 6), ESP is the teaching of English used in academic studies or the teaching of English for vocational or professional purposes. 
Therefore, Alwasilah (1997:86-87) states that English for university students must not be concentrated on media but more on the substance of specialization that is covered by language. I believed that what has been stated by Alwasilah above followed the idea of ESP given by Hutchinson and Waters.

However, the implementation of ESP for university students in Indonesia is truly ideal. In other part of his explanation, Alwasilah (1997) described that from language psychology point of view students of most universities in Indonesia were considered as students who had advanced cognitive skills but were still low in English skills.

The fact that the English ability of graduate of Senior High Schools is low is also supported by Menurut Gunawan (2003). He explained that graduates students of Senior High School were assumed to have many knowledges of and partial skills of English but those knowledges and skills could still not be used actively in daily communication. In addition, the former Ministry of National Education Wardiman Djoyonegoro in one occasion of seminar in Central Java (25/5/2011) said that only few graduate of Senior High School have standard ability in English. Suherman (2012) also described that because of substantial mistake of teaching English at Senior High School, when students graduated from Schools they could not use of English for active communication.

Regarding the real condition above, I understood that it was not really ideal to implement ESP for Architecture, Pharmacy and Psychology students as there were many pre-requisites problems should be solved first before taking ESP to those classes. Therefore, I decided to propose Formula 33 in the process of learning English.

This decision was actually followed Alwasilah's (1997:87) suggestion to conduct students' need analysis. He explained in quite long propositions that the typical characteristic of English in the Senior High School was that university students' ability were very heterogeneous. Students' need analysis would articulate their hopes and needs in learning English as well as showing the map of their ability in English. Without this analysis, teaching English at universities was only travelling on the earth without destination amid the jungle of uncertainty.

Therefore, the students' need analysis was done by asking students to write down their weaknesses in learning English as well as what they wanted to study at that time. The results of need analysis on weaknesses are displayed in table 1. 
Table 1: Students' Weaknesses

\begin{tabular}{ccc}
\hline No & Weaknesses & Total Data \\
\hline 1 & Grammar & 124 \\
\hline 2 & Vocabulary & 118 \\
\hline 3 & Conversation / Speaking & 110 \\
\hline 4 & Understanding of The Word of Sentences & 52 \\
\hline 5 & Difficulty to answer questions in TOEFL \& TOEIC & 26 \\
\hline 6 & Listening & 23 \\
\hline
\end{tabular}

In addition, the results of need analysis on hopes are displayed in table 2.

Table 2: Students' hopes to learn

\begin{tabular}{lcc}
\hline No & Hopes & $\begin{array}{c}\text { Total } \\
\text { Data }\end{array}$ \\
\hline 1 & Understand about grammar and tenses & 165 \\
\hline 2 & Communicate Independently with another people / speaking english & 151 \\
\hline 3 & Have a lot of Vocabulary & 97 \\
\hline 4 & Succeed in TOEFL \& TOEIC & 47 \\
\hline 5 & Be able to translate the word or sentences & 44 \\
\hline
\end{tabular}

The table 1 and 2 above show that grammar and tenses are English topic that students' lowest ability and most wanted to learn. Therefore, I decided to propose Formula 33 to be the main concern on the learning English for them. This formula was created by Gunawan (2003) that he drew the learning design in the table 3.

Table 3: Learning Design

\begin{tabular}{|c|c|c|}
\hline \multicolumn{3}{|c|}{ MESIN } \\
\hline $\begin{array}{l}\text { Kalimat bhs. } \\
\text { Indonesia/ }\end{array}$ & $\begin{array}{l}\text { PENGINGGRIS } \\
\text { (LAD - Language }\end{array}$ & $\begin{array}{c}\text { Kalimat } \\
\text { bhs. }\end{array}$ \\
\hline Bhs. Daerah & $\begin{array}{c}\text { Acquisition } \\
\text { Device) }\end{array}$ & Inggris \\
\hline
\end{tabular}


According to Gunawan (2003), the Formula 33 is also a derivation of several linguistics concepts. The first is the concept of Pragmatics; the second is the concept of VNP; the third is the concept of Time; the fourth is the concept of Aspect; and the last is the concept of Formula's Character.

\section{The Concept of Pragmatics}

In the concept of language pragmatic, stipulate definition of language is formulated simply as a sentence. Language will be useful when the speaker acts the language. Because language is a sentence; so, language act is using the sentence. When a speaker using sentence, $\mathrm{s} /$ he is producing and receipting sentences.

Producing language by using mouths and receipting it by using ears is called spoken language. Producing language by using hands and receipting it by using eyes is called written language. Producing language by using mouths is called speaking. Receipting language by using ears is called listening. Producing language by using hands is called writing. Receipting language by using eyes is called reading. Speaking, Listening, Writing, and Reading are four skills done by a speaker when they use the language.

\section{The Concept of VNP}

English sentence is divided into 3 types. The differentiator of the three is the subject behaviour. The first type is a sentence that its subject does an action and it is called verbal active sentence (V). The second sentence is a sentence that its subject does not do an action nor is subject to the action and it is called nominal sentence $(\mathrm{N})$. The last type is a sentence that its subject is subject to the action and it is called verbal passive sentence. In short, the three sentences are abbreviated into VNP.

Each of VNP has 16 variations; therefore, there will be $16 \times 3$ to make up 48 sentences. However, as the principle of learning foreign language is to learn the most frequently used language, only 11 variations will be learnt. It is obvious then there are $11 \times 3$, so the total is 33 sentences. As a matter of simplicity it is then is called Formula 33. The figures of Formula 33 can be seen in the table 4 . 
Table 4: Formula 33

\begin{tabular}{|c|c|c|}
\hline $\begin{array}{c}\text { Verbal A ctive Sentence } \\
\text { (V) }\end{array}$ & $\begin{array}{l}\text { Nominal Sentence } \\
\text { (N) }\end{array}$ & $\begin{array}{c}\text { Verbal Passive Sentence } \\
\text { (P) }\end{array}$ \\
\hline 1. kerja & 1. is/am/are & 1. is/am/are kerjaed 2 \\
\hline 2. will kerja & 2. will be & 2. will be kerjaed ${ }_{2}$ \\
\hline 3. is/am/are kerjaing & 3. is/am/are & 3. is/am/are being kerjaed ${ }_{2}$ \\
\hline 4. kerjaed $_{1}$ & 4. was/were & 4. was/were kerjaed 2 \\
\hline 5. have kerjaed 2 & 5. have been & 5. have been kerjaed 2 \\
\hline 6. would kerja & 6. would be & 6. would be kerjaed 2 \\
\hline 7. was/were kerjaing & 7. was/were & 7. was/were being kerjaed ${ }_{2}$ \\
\hline 8. will be kerjaing & 8. will be & 8. will be being kerjaed ${ }_{2}$ \\
\hline 9. had kerjaed 2 & 9. had been & 9. had been kerjaed 2 \\
\hline 10. will have kerjaed ${ }_{2}$ & 10. will have been & 10. will have been kerjaed ${ }_{2}$ \\
\hline 11. have been kerjaing & 11. have been & 11. have been being kerjaed ${ }_{2}$ \\
\hline
\end{tabular}

\section{The Concept of Time}

Time is divided into three, i.e. past, present, and future. Present is further divided into now or at present time, and period of time. The time can be attached in the sentence and it is often not. There will be three groups of formula for time in relation to Formula 33. They are:
a. Present : $1,3,5,11$
b. Past : $4,6,7,9$
c. Future :2,8,10

\section{The Concept of Aspect}

Aspect is the accentuation on process or state of being. There are four aspects in English progressive, perfective, future, and nothing. Both progressive and perfective can happen in at all time, while future aspect can only happen in the past time. As not all sentences must accentuate the process or state of being, the fourth aspect is nothing. When they are involved in the Formula 33, the division will be:
d. Progressive :3,7,8, dan 11;
e. Perfective :5,9,10, dan 11 ;
f. Future : 6;
g. Nothing $: 1,2$, dan 4 . 


\section{The Concept of Formula Character}

Formula Character is a combination of Formula of Time and Formula of aspect. By combining the two, the one and only formula will be determined. This formula is definite and cannot be exchanged. The formula character is showed in table 5 .

Table 5: Formula Character

\begin{tabular}{lccccc}
\hline ASPECT & Progressive & Perfective & Future & Nothing & $\begin{array}{l}\text { Progressive and } \\
\text { Perfective }\end{array}$ \\
\cline { 1 - 5 } TIME & & & & & 11 \\
\hline PRESENT & 3 & 5 & - & 1 & - \\
\hline PAST & 7 & 9 & 6 & 4 & - \\
\hline FUTURE & 8 & 10 & - & 2 & \\
\hline
\end{tabular}

By comprehending Formula 33, students are able to recognize in the spoken and written form of English sentences. They can also write any kinds of Basic English sentences. Not only that, Formula 33 can also develop for four skills of language.

\section{DISCUSSION}

The results of sorting and classifying keywords bring about three themes that are presented in the diagram 1 .

\section{Diagram 1: Themes}

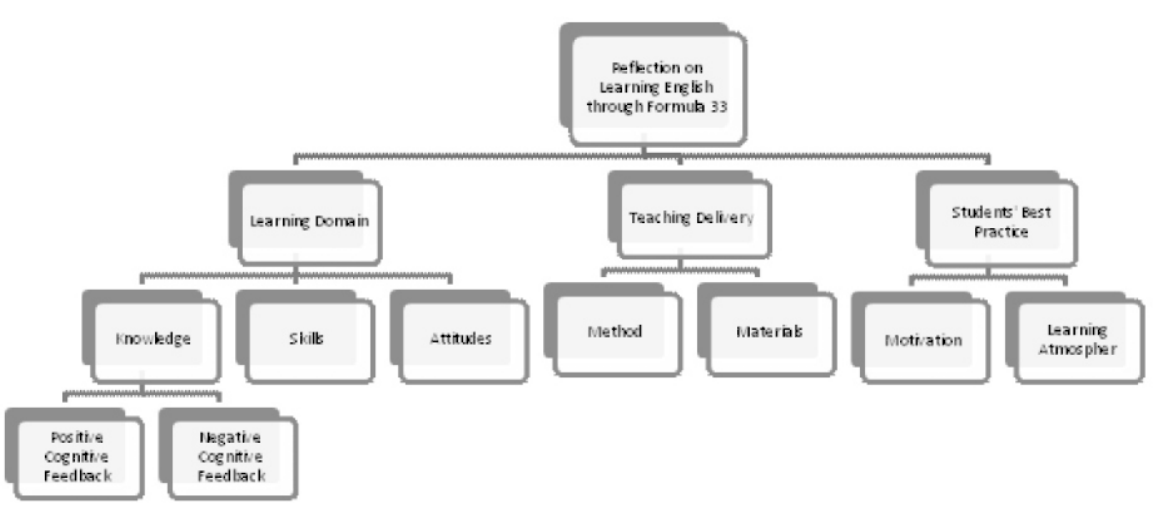


The results of students' reflection on learning English through Formula 33 are divided into three themes learning domain, teaching delivery, and students' best practice. Each theme will be described in details as follows.

\section{Learning Domain}

From the learning domain's point of view, students' reflection can be classified into knowledge, skills and attitude.

\section{Knowledge}

The explanation of three steps of activating Formula 33 could be understood by students and they got new knowledge about it. Most of their reflection are expressed in the keyword understand and the like for positive cognitive feedcack and do not understand and the like for negative cognitive feedback.

\section{Positive Cognitive Feedback}

Step-by-step delivering system of Formula 33 made students understand the concept from its base. The first thing that students must comprehend was the concept of VNP. Most students understand the concept.

The two following excerpts represented students' reflection of this theme. "When you gave the material, I try to answer your question with all of my "book" knowledge. But, actually you success make me think twice to how understand a language from zero.,., and the last Nice to know your VNP formula. Now I am able to understand more in analyzing what sentence belongs to." (The above expression was written by students in English and it is displayed as it is without editing).

The other expression is in the followings. "At this meeting, I become more understand about determining sentences based on VNP method as you teach. Frankly speaking, I have just known VNP at this meeting. I thank you because by this method I can understand more about VNP, and also I can classify sentences easily. I understand the material."

Further concept of VNP was Formula 33 in which students also did the same way. Most students understand how to figure out Formula 33. One example of excerpt said, "Formula 33 help me much in learning English. It is not only about theories that Mr. Nizam taught but it is also completed with some practices done one by one. This makes me understand VNP and Formula 33." 
When students came to activation session, most of students expressed positive cognitive feedback. One of the quoted sentence,"I understand more how to activate Formula 33 in English sentence" represented from many other reflection written by students. Other quoted sentences are as follows:

"Sentences of Formula 33 make me understand more on differentiating time and aspect."

"Playing with determining VNP, time, and aspect make me know more the structure of sentences."

"By experiencing many exercises, I understand how to activate Formula 33, Sir."

Furthermore, students realized the step-by-step application of Formula 33 made them understand the basic concept. They used to learn English instantly at Senior High School but they did not know its concept. Here is the quotation, "Through Formula 33, I can apply for tenses that often learnt at Senior High School instantly without knowing what the concept of tenses is. Now, I can apply that well. thx sir ;)."

Not only understand the concept, students also realized themselves on mistakes they made in the sentences. Realizing their weaknesses with easy method of learning made students were eager to learn more and more.

Here are the quoted sentences in Bahasa Indonesia,"Saya mulai bisa menangkap maksud istilah Pak Nizam tentang 'mengaktifkan mesin peng-inggris'. Metode ini cukup efektif khususnya bagi mereka yang benar-benar buta grammar dan konteks kalimat dalam bahasa Inggris. hal yang unik adalah, kegiatan mentranslate kalimat menjadi seperti ilmu eksak dimana kita dihadapkan pada rumus \& tabel. Goodjob."

\section{Negative Cognitive Feedback}

It seems universal way to see the contrast reality that there were some students who did not understand the concept Formula 33. Generally, they expressed it with confused or less understandable. Here are the quoted sentences in Bahasa Indonesia:

"Saya coba buat memahami konteks dan maksud dari kalimat itu, tetapi sangat membingungkan hehehe."

"Sbnrnya ya pak, sya tu msi kurang fham tntg aktivasi kalimat formula 33, tapi saya mencoba untuk memahaminya dengan sebaik mungkin."

"Saya masih bingung dan perlu lebih banyak latihan lagi." 
"Aktivasiformula 33, cukup membingungkan."

"Formula 33 nya masih membingungkan pak."

"Saya masih bingung dengan penggunaan formula 33."

"Sejujurnya saya masih bingung pak, masih kurang paham. Saya akan tetap berusaha sebaik mungkin pak:D."

"Materi rumus formula 33.. saya masih kesulitan."

"Aktivitas kalimat rumus 33 kurang di mengerti pemaham VNP nya."

"Saya masih bingung dalam menentukan apakah kalimat itu V, Natau P."

"Untuk aktivasi kalimat formula 33 saya masih bingung pak mengenai penembakan VNPnya."

"Mengenai aktivasi kalimat formula 33, saya masih kurang mengerti. Terutama dalam penentuan waktu 'sekarang', masih agak bingung pak apakah kalimat tersebut termasuk dalam kategori sekarang atau lampau."

"Saya belum mengerti tentang penonjolan keakanan pak... mohon bimbingannya mmhh. cukup membingungkan pak.. awalnya mudah untuk menghafal, tapi saat diterapkan di waktu dilakukannya quis, membingungkan pak.. suka tertukar-tukar."

From the above description, students were confused in applying Formula 33 but they did not state it specifically. There were some students who wrote their confusing specifically. The things were the VNP, the present time and the aspect of future.

\section{Skills}

From the explanation of the concept of VNP, some students wrote that they were able to differentiate, determine nominal, verbal, and passive sentences well, correctly, and quickly. Besides, they practiced the skills of VNP outside classroom because they have beneficial skills to analyze sentences through VNP.

Furthermore, keywords highlighted from students' reflection to consider that they were skilful on Formula 33 were able to use, could learn by heart, and able to do. From the students' reflection it was noted that most students found easier way to memorize and understand the tenses. They expressed in many variance of memorizing such as,"Now, I know fast and easy way to memorize tenses," or ,"Formula 33 is easier to be memorized with your method." Another student wrote," Formula 33 was spectacular, Sir. It is east to memorize it." 
Here are other quoted sentences from students' reflection:

"Formula 33 is very efficient to memorize. Thanks, sir."

"Formula 33 makes me easy to memorize it. Thankyou."

"Formula 33 is very interesting, so it is easier to be memorized. Thanks, Sir."

"Formula 33 is an easy and a unique way to memorize and to understand tenses."

"For Formula MAU-MAU (3? Mau? Is the advertisement of IT provider) is an easier and fast memorizing way, Thank you Sir for tricks and tips."

One data saying that he has been struggling form more than 3 year to understand tenses and it did not work at all. By learning Formula 33, he could make it with formula 33. Here is the original quoted sentence without editing,"I need more than 3 years to understand the tenses, and its really not success. But I think now, I can handle it with your 33 Formula." The same thing was expressed by other student who was saying,"I think it's impossible to understand TENSES, but after finding new methods formula MAU-MAU (33) and irregular verbs from you. Two thumbs up for you, Sir. : DD."

From what students wrote about Formula 33 above, it was understandable that memorizing 16 tenses was not easy to do. However, Formula 33 facilitate students with easy, fast, and unique way to memorize tenses.

\section{Attitudes}

Learning must be pleasureable for students and it happened when students were taught by the concept of VNP. It expressed with the word pleased, very pleased, cool, enjoyable, impressed, very impressed, amazing, and very enjoy.

What is more, the concept of VNP could change students's attitude toward English. Before they learnt the concept of VNP, they still thought that English was difficult, scary, and disliked. The attitude changed when they leart the concept of VNP. Students became more vibrant to learn English, "More vibrant to learn English...I was used to scary with English lesson; I used to dislike English, Now, I like it; Sir, thank you so much coz u, I love English,, English so fun, English so easy :)." (note: authentic) . Other said it was very pleased,"It was very pleased that I consider English was scary before." The other commented that s/he was not scary and felt so bad,"You didn't make me scares and feel so bad (Note: authentic), and the materials was very pleased." It was also found that student wrote, "English seems to be more ringing and is easier to be learnt when I study Englis." 
Furthermore, student also said that the concept of VNP made their tortures when learning English was diminished. Student also saluted with the very enthusiast way of teaching," Salute for you who are always very enthusiast teaching although the learning time is in the afternoon. Good job, Sir!' Because student like learn English, s/he consider the lecturer her/his favorit, "You are one of my favorite lecturers."

Many data of students' reflection expressed their attitude on Formula 33. The keywords for attitude on Formula are pleased, interesting, cool, exciting, helpful, and understandable.

Here are the quoted sentences for pleased:

"Formula 33 is pleased."

"Formula 33 is very pleased."

"The topic about Formula 33 is pleased and is easy to understand."

"Formula 33 is very pleased and easy to understand, Sir."

"Formula 33 is very pleased, particulary in the sub topic of irregular verbs.

:D Amazing, right!

"The topic of Formula 33 is very plased especially for me."

"The topic of Formula 33 is pleased, Sir!

Another keyword is interesting. Here are the quoted sentences:

"The yesterday topic of Formula was interesting."

"Formula 33 that you teach is very interesting, I become easy to understand and to learn it."

"Formula 33 is different from one that is taught at school. It is interesting and I am trying to memorize and understand it."

"In my ind, Formula 33 is very interesting."

"Formula 33 that you teach is interesting to learn."

"The topic of Formula 33 that you teach is interesting. I haven't got it yet and it seems easy to memorize."

"Formula 33 is interesting enough because this is my first experience to learn tenses through VNP with concept of $3 x$ ll like this."

Other data showed that students liked Formula 33 very much because they did not necessary to memorize the name of tenses like past tense, continous tense, etc. They just memorize Formula 33. The other reason is that students change their mind in the respect of wrong assumption about tenses. They experienced from the way they got from school that memorizing 16 tenses was very difficult. Through 
Formula 33 they think otherwise. Here is the example quoted sentence:

"Pembelajaran formula 33 nya sangat baik pak, saya lebih memahami cara yang bapak ajarkan di bandingkan cara yang dulu saja pelajari di SD, SMP, SMA."

"Thanks buat formula 33, alhamdullilah saya merasa lebih bisa memahami bahasa Inggris dengan baik karena adanya formula 33.,,, asikgila...!"

"Formula 33 menjadi mempunyai bayangan dan mempermudah dalam mengerjakan soal materi kmrn tetap mnarik...coba dari dulu guru b.inggris saya pak nizam.... psti skrg saya udah lncar bget berbhasa inggris dgn baik dan benar... hehehe."

Furthermore, it was stated that Formula 33 was exciting. Here are the quoted sentences:

"Formula 33 nya itu seru pak lucu tapi bisa gampang buat di pelajari dan di ingat dalam penggunaan kalimat."

"Materi formula 33 dan kata kerja tidak beraturannya seru pak."

"Belajarnya kemaren seru banget pakngga buat ngantuk pkoknya."

"Materi tentang formula33 dan kktdk beraturan seru pak..."

Other said that Formula 33 was cool. Examine the quoted sentences below:

"Materiformula 33 \& kta krja tdk beraturan,, asyik pak.."

"Kemaren belajarnya asikpaa."

"Mtrinya alhmdulilah bs d trma dg baik, aplgi kta kurang ajrny heee, mngasyikkan.trmksih."

"Utk frmla 33 sgtasyik+mdh d'mgrti."

"Pelajaran hari ini, sangat asyik dan menantang buat saya."

"Formula 33 nya mantap!"

What is more, student found that Formula 33 was very helpful. Here the quoted sentences:

"I think the formula 33 and KK tidak beraturan was very helpful for us."

"Formula 33 that you have given for us, it was very helpful and I hope my English skills will be increase :)."

"Formula 33 sangat membantu saya untuk menginggriskan kalimat inggris pak setelah mendapatkan materi 33 sebenarnya pada awalnya saya agak bingung tapi waktu dipraktikan kemarin alhamdulillah sedikit membantu."

"Formula 33 sangat membantu sekali untuk saya belajar bahasa inggris apalagi tidak hanya teori" belaka yg bapak ajarkan namun dengan percobaan soal" sehingga lebih mudah untuk dipahami."

"Kuis VNP dan menentukan formula 33 berdasarkan waktu dan aspeknya sangatmembantu" 
"Mr Nizam I'm very happy because formula 33 make me easy about study English." "I'am verry happy in this day, because formula 33 make me easy to study english:)."

"Materi formula33 nya cukup mudah d pahami dn di hafal .:)"

"Formula 33 nya, cukup mudah untuk diterima."

"Formula 33 dan kata kerja kurang ajar bisa diterimalah,, lanjutkan."

There were students who just wrote simply that Formula 33 was the best, amzing, efficient, and challenging. Here are the quoted sentences:

"Materi formula 33 sama kata kerja tidak beraturannya the best."

"Materiformula 33 nya, amazing."

"Rumus 33 tersebut sangat membuat efisien."

"Formula 33,cukup menantang. "

There were a group of students who wrote their reflection in English. Here are their reflections:

"How amazing your material today. with your theory about waktu and aspek make me understand about translate indonesian to english with easy."

"I think the theory about TIME and ASPECT method is attractive. I hope $i$ can more understand about that . thumb up for you."

"Just by know your 3 method (VNP, Irregular verb and 33 Formula) make me comfortable to learning english more..."

"I was happy about material yesterday,,easy understand,, although difficult but material who teaching more understood easy thank you."

"I think "fabulous" for the complete english machine, especially for formula 33. thumbs up."

"Mr. Nizam, i am very proud with your formula about FORMULA 33 and irregular verbs."

What an interesting reflection below. The student analogized formula character with human characters. Here are the quoted sentences:

"Watak rumus yang bapak ajarkan sangat menarik, sprt kita sdang mempelajari watak manusia, tapi bedanya, dsni kita diajarkan untuk mengenal watak rumus b.inggris, dan jika kita tidak tau wtak rumus tersebut, kita tidak akan bisa mengenali b.ing lebih dalam."

\section{Teaching Delivery}

From the teaching delivery side, students' reflection can be classified into method and materials. 
"Mr Nizam I'm very happy because formula 33 make me easy about study English."

"I'am verry happy in this day, because formula 33 make me easy to study english:)."

"Materi formula33 nya cukup mudah d pahami dn di hafal .:)"

"Formula 33 nya, cukup mudah untuk diterima."

"Formula 33 dan kata kerja kurang ajar bisa diterimalah,,lanjutkan."

There were students who just wrote simply that Formula 33 was the best, amzing, efficient, and challenging. Here are the quoted sentences:

"Materiformula 33 sama kata kerja tidak beraturannya the best."

"Materiformula 33 nya, amazing."

"Rumus 33 tersebut sangat membuat efisien."

"Formula 33,cukup menantang. "

There were a group of students who wrote their reflection in English. Here are their reflections:

"How amazing your material today. with your theory about waktu and aspek make me understand about translate indonesian to english with easy."

"I think the theory about TIME and ASPECT method is attractive. I hope $i$ can more understand about that . thumb up for you."

"Just by know your 3 method (VNP, Irregular verb and 33 Formula) make me comfortable to learning english more..."

"I was happy about material yesterday,,easy understand,, although difficult but material who teaching more understood easy thankyou."

"I think "fabulous" for the complete english machine, especially for formula 33. thumbs up."

"Mr. Nizam, i am very proud with your formula about FORMULA 33 and irregular verbs."

What an interesting reflection below. The student analogized formula character with human characters. Here are the quoted sentences:

"Watak rumus yang bapak ajarkan sangat menarik, sprt kita sdang mempelajari watak manusia, tapi bedanya, dsni kita diajarkan untuk mengenal watak rumus b.inggris, dan jika kita tidak tau wtak rumus tersebut, kita tidak akan bisa mengenali b.ing lebih dalam."

\section{Teaching Delivery}

From the teaching delivery side, students' reflection can be classified into method and materials. 


\section{Method}

Some other students were writing about the method. Some wrote in short but other wrote in quite long expressions. Students who wrote in short phrases said that the method was good, cool, unique, and exciting. There were short and precise reflection, "Your teaching style, I just like it, Your method is easy to follow, Your method is not boring, Your explanation is easy to understand, A very correct way to learn English;) thankyou sir:), and lecture's method is interesting.

Other students wrote in quite long sentences. The students used several variances of keywords such as teaching with enjoyable technique, the way you explain, your explanation, your material delivery, and the way you teach.

The excerpts are, "You teach with enjoyable technique and make students easy to memorize what you have explained; The way you explain make me easier in differentiating which active, passive, and nominal sentences; Your explanation is very easy to understand, making English seems to be a piece of cake; Thank you, Sir, for your delivering easy and enjoyable English make me able to differentiate VNP sentences are understood easily. Thanks, Sir :); The method of teaching use is very interesting and not boring so the materials are easier to understand; According to me, the way you teach is very good, thanks!; The method you used is very interesting and is able to differentiate the sentences of verbal, nominal, and passive easily. I like it. Thank you sir! The method is fun, and the delivery of materials is easy to understand.

Furthermore, some students wrote that Formula 33 was getting interesting from meeting to meeting; the delivery was relaxed, passionate, and easy going; it was creative and innovative; and the method was exclusive. Here are the quoted sentences:

"Menurut saya, metode yang bapak berikan di setiap pertemuan semakin menarik, membuat saya semakin tertarik dengan bahasa inggris, dan semoga dengan bertambahnya pengetahuan saya tentang metode ini, akan membuat saya lebih mudah menulis dan membedakan jenis kalimat. terimakasih pakNizam :)"

"Mengenai cara mengajar bapak yang mantap, bapak selalu membawakan materi dgn santai dan penuh gairah..terus maju pak..lanjutkan; lebih cepat lebih baik ....!!! :):);;;;O."

"Pngjran mr nizam yg kreatif dan inovtif mmbwat sya dan mngkin tmn2 lainny bs memhminya dg cpet." 
"Saya sangat menyukai cara mengajar bapak yang easy going , yang bisa membuat saya lebih mudah dalam menyerap pelajaran. Semoga saya bisa meningkatkannya lagi melalui kuliah bapak."

"Metode yang diberikan juga lain dari pada yang lain..sangat bermanfaat untuk pemahaman bahasa inggris saya."

There were some students who wrote their reflection in English. Here are the quoted sentences:

"Your method is easier to understand and change my mindset in translate of sentences in English."

"It is new method that I have known."

What a good method, sir! Yeah, so easy to understand it with formula 33

What the important fact that there was one student who realized that this method was designed to help students learn English independently. Here is the quoted sentence:

"Melihat metode yang singkat tersebut saya rasa dengan belajar sendiripun sayabisa memahaminya."

\section{Materials}

Some students were commenting about the materials. They expressed the material given mostly with adjectives words. They wrote that the materials are interesting, enjoyable, cool, effective, helpful, pleased, good, favored, and marvelous. In addition, one datum found that the material was relative new but favorable. Another datum said that the student has just known the concept of VNP which was very enjoyable and was easy to follow. The student wrote: "I have just known that there was a concept of VNP... and it was enjoyable and was so easy."

Furthermore, materials given were also expressed by students with the word understand in its superlative variant. There are eight data saying that the materials were easy to be understood, and followed by phrases of very much understandable, less understandable, and of making understandable.

Other expression used by students in writing about material is the phrases of making easy to understand or the like. The variances were quite great. Some excerpts from students reflection were: "The materials make me easy to understand and to learn English" (3 data), "The materials that you given make me easier to understand verbal, nominal, and passive sentences." Other student wrote," Learning English is easier and quicker by knowing verbal, nominal, and 
passive" while the other student put on paper," The material that you given today make learning English easier that I understand more about verbal, nominal, and passive sentences."

The last key word used by students is the word helpful. Some expressions were: "I become understand about sentence to help me in differentiating sentences, the material about verbal, nominal, and passive sentences help me to learn English easily, and this material help continuance of student learning, it is very helpful in learning English."

\section{Best Practice}

From the students' best practice aspect, students' reflection can be classified into motivation, hopes, learning atmosphers, difficulties, and awareness.

\section{Motivations}

The first material that was the concept of VNP encourages student to learn English. The keywords found here were become vibrant, trigger, encourage, give motivation, give a light, and enlightment. Here are the quoted sentences:

"About VNP, I become more vibrant to learn English. Thanks sir."

"I become vibrant to attend the English class to learn VNP. It was very cool.

Thanks sir."

"It englihtens me to learn English more and more."

"This material encourages me to learn English."

"You have motivated me to learn English. I don't understand English for long time but by your method I am encouraged to learn English. Hopefully, I can understand English better."

"I get enlightment and hope to learn English..... Thank you sir....."

Some students wrote their reflection in English. Here are the quoted sentences:

"We are waiting for your NEXT FORMULA, sir. Thankyou:) Great!!!! Now, my "english machine" completely installed. Hope There will be another program from you that can make my CPU have various program to learn english more." 
"I hope i can learn with your theory in the next time."

"I must learn learn and learn more .. thank's for your great formula sir."

"I hope with your 33 formula, i can easily to remember about the tenses. And also about the method that you taught about regular and irregular verb xyx xyy xxy and so on, $i$ wish $i$ can easily identify where it should be belong.

Thankyou so much sir ;)"

"That's new knowledge for me and i'll try formula 33 in home."

"I hope I can easy to understand more about tenses."

"I will try to understand your 33 formula."

\section{Learning Atmosphere}

One of good impacts felt by students was that they were not sleepy during the class; they still wake up and energetic; the learning is relaxed but getting focus. Here the quoted sentences:

"It did not make me sleepy (8 data)."

"I am pulsating and alive".

"The learning is relazed but getting focus."

"It is exciting to learn English with you. It is very interesting because it is 